\title{
MORPHOMETRIC STUDIES ON DWARF HONEY BEE APIS FLOREA F. WORKERS IN SAUDI ARABIA
}

\author{
Saad N. AL-Kahtani ${ }^{1}$ \\ EL-Kazafy A. Taha ${ }^{1,2 *}$ \\ ${ }^{1}$ Department of Arid Land Agriculture, College of Agriculture and Food Sciences, King \\ Faisal University, Al-Hasa, Saudi Arabia \\ 2 Deptartment of Economic Entomology, Faculty of Agriculture, Kafrelsheikh University, \\ Kafrelsheikh, Egypt \\ *corresponding author: kazafy_taha@yahoo.com \\ Received 26 September 2013; accepted 16 April 2014
}

\begin{abstract}
Here we performed a morphometric analysis of dwarf honey bee (Apis florea F.) workers from Saudi Arabia, and we detected morphometric variations within the species in the Jubail and Al-Ahsa provinces of this region. Between the two provinces, Jubail is further north and is closer to sea level, and data showed that during the collection period, Jubail experienced significantly higher humidity. Compared to workers from the Jubail province, workers from Al-Ahsa province showed significantly higher body weight, measured head appendage characteristics, wing characteristics (apart from hindwing width), leg characteristics, and length and width of the $3^{\text {rd }}$ abdominal sternite and $1^{\text {st }}$ wax mirror. Body weight as found to be significantly positively correlated with all determined characteristics, except for flagellum length, hindwing width, $3^{\text {rd }}$ tergite length, and lengths of the $4^{\text {th }}$ tergite and sternite. It can be concluded that body weight and morphometric characteristics of dwarf honey bee workers were significantly affected by geographic origin. The morphometric measurements were within the range reported from most previously examined countries.
\end{abstract}

Keywords: Apis florea, dwarf honey bee, morphometric, Saudi Arabia.

\section{INTRODUCTION}

Dwarf honey bees (Apis florea F.) are important in agriculture, medicine, and the environment (Free, 1981). They are an excellent pollinator of various economic crops and forest plants, and they have a wide foraging range (Wongsiri et al., 2000; Tahmasebi et al., 2002). The species is now well established in Sudan, where it was first detected in 1985 (Mogga and Ruttner, 1988), as well as in Iraq, Oman, and Yemen (Wongsiri et al., 1996). This bee has recently also been detected in Jordan (Haddad et al., 2008, 2009) and central Saudi Arabia (Hepburn et al., 2005), and has become widely distributed in the eastern region of Saudi Arabia. Throughout this expansion along the Arabian Peninsula and into Africa, it appears to have successfully colonized and become well adapted to the hot arid conditions of both urban and bucolical landscapes, being uninfluenced by competition from any local Apis mellifera (El-Shafie et al., 2002).
Morphological studies have been performed on A. florea from India (Bhandari, 1983; Sharma, 1983; Ruttner, 1988; Hepburn et al., 2005); Iran (Ruttner, 1988; Tahmasebi et al., 2002; Hepburn et al., 2005); Oman and Pakistan (Ruttner, 1988; Hepburn et al., 2005); Sri-Lanka (Ruttner, 1988; Hepburn et al., 2005); Thailand (Ruttner, 1988; Rinderer et al., 1995; Chaiyawong, 2001; Chaiyawong et al., 2004; Hepburn et al., 2005); Cambodia, Myanmar, Nepal, and Vietnam (Hepburn et al., 2005); and Jordan (Haddad et al., 2009). These investigations have revealed inter-locality variations in most of the morphometric characteristics measured in $A$. florea workers. Tahmasebi et al. (2002) studied the effects of geographical and climatic conditions on the morphological variations among Iranian small honey bees (A. florea F.), and found two distinct populations: a class of larger bees residing in the southwest of Iran, and a class of smaller bees residing in the southeast of Iran. Similarly, Bhandari (1983) and Sharma (1983) each reported significant inter-locality differences in the mean values of morphometric characteristics and 
in the coefficients of variation for most characteristics measured in $A$. florea $\mathrm{F}$. in India.

The present study aimed to investigate the morphometric characteristics of dwarf honey bee $A$. florea $\mathrm{F}$. workers under the environmental conditions present in Saudi Arabia. Our second goal was to detect the variation within this species between two provinces in this region.

\section{MATERIAL AND METHODS}

These investigations were conducted at the laboratory of the Department of Arid Land Agriculture, College of Agriculture and Food Sciences, King Faisal University, Al-Ahsa, Kingdom of Saudi Arabia. During the sidir (Ziziphus spp.) season from midSeptember to mid-November of 2011, 80 Apis florea colonies were selected from the Al-Ahsa and Jubail provinces (forty colonies from each). Al-Ahsa lies at latitude $25^{\circ} 25^{\prime} 46^{\prime \prime} \mathrm{N}$ and longitude $49^{\circ} 37^{\prime} 19^{\prime \prime} \mathrm{E}$ and an altitude of $121 \mathrm{~m}$ above sea level, while Jubail is at latitude $27^{\circ} 0^{\prime} 16.0^{\prime \prime} \mathrm{N}$, longitude $49^{\circ} 39^{\prime} 41.0^{\prime \prime} \mathrm{E}$, and an altitude of $12 \mathrm{~m}$ above sea level.

From the selected colonies, parts of combs containing ripe worker sealed broods were cut and inserted into wooden cages $(15.5 \times 12 \times 12 \mathrm{~cm})$ with three sides of metal net. These cages were then placed into an incubator at $31^{\circ} \mathrm{C}$ and relative humidity (R.H.) of 45 until workers emerged. Within $3 \mathrm{~h}$ of emergence, 50 newly emerged workers were collected from each cage. The workers were chilled, and then their fresh body weights (in $\mathrm{mg}$ ) were determined using an electronic scale. They were then preserved in $70 \%$ ethanol until dissection.

The eighteen morphological characteristics examined in this study were proboscis length, flagellum length, total antenna length, length and width of right forewing and hindwing, number of hamuli on the right hindwing, femur length, tibia length, and width of the end of tibia, length of the $3^{\text {rd }}$ and $4^{\text {th }}$ abdominal tergite and sternite, and length and width of the $1^{\text {st }}$ wax mirror. The examined body parts were removed and placed on glass slides to measure the lengths and widths (in mm) using a dissecting binocular microscope equipped with a micrometer lens.

During the experimental period, meteorological data (air temperature, relative humidity, wind velocity, rainfall, and soil temperature at $5 \mathrm{~cm}$ ) were obtained from the Meteorological Station of Agricultural and Veterinary Training and Research Station, King Faisal University, Al-Ahsa, as well as from Royal Commission for Jubail, Kingdom of Saudi Arabia. Data were recorded using Campbell Scientific CR 3000.
Data were statistically analyzed by ANOVA. Pearson correlation between characteristics was determined using SAS Institute (2003).

\section{RESULTS}

The obtained data showed that body weight and 14 of the 18 examined morphometric characteristics of dwarf honey bee (Apis florea) workers were significantly affected by geographic location (Tab. 1). Compared to those from Jubail province, workers from Al-Ahsa province exhibited significantly higher values $(p<0.01)$ for body weight, proboscis length, flagellum length, total length of antenna, forewing length and width, hindwing length, number of hamuli, tibia length and width, and $1^{\text {st }}$ wax mirror width. The values for femur length, metatarsus length, $3^{\text {rd }}$ sternite length, and $1^{\text {st }}$ wax mirror length were also significantly higher (at the significance level of $p<0.05$ ) than those of workers from Jubail province. Four morphometric characteristics (hindwing width, $3^{\text {rd }}$ tergite length, and lengths of the $4^{\text {th }}$ tergite and sternite) were not significantly affected by colony location.

Body weight was significantly positively correlated with all determined characteristics, except for flagellum length, hindwing width, $3^{\text {rd }}$ tergite length, and lengths of the $4^{\text {th }}$ tergite and sternite. Forewing length was also found to be significantly positively correlated with proboscis length, antenna length, forewing width, hindwing length, tibia length and width, $3^{\text {rd }}$ sternite length, and $1^{\text {st }}$ wax mirror length and width. Third sternite legth was also found to be significantly positively correlated with all determined characteristics, except for proboscis length, hindwing width, $4^{\text {th }}$ sternite length, and $1^{\text {st }}$ wax mirror length and width. We also found that $1^{\text {st }}$ wax mirror width was significantly positively correlated with proboscis length, antenna length, forewing length and width, hindwing width, number of hamuli, determined leg characteristics, and $1^{\text {st }}$ wax mirror length (Tab. 2).

The relative humidity values obtained for Jubail province were significantly $(p<0.05)$ higher than those of Al-Ahsa province. During the experimental period, air temperature, wind velocity, rainfall, and soil temperature did not significantly differ between the two locations (Tab. 3). 


\section{J. APPC. SCL. VOL. 58 N NO. 12014}

Table 1.

Mean body weights and average measurements of 18 morphometric characteristics of dwarf honey bee (Apis florea) workers collected from the Al-Ahsa and Jubail provinces

\begin{tabular}{|c|c|c|c|c|}
\hline \multirow{2}{*}{\multicolumn{2}{|c|}{ Character }} & \multicolumn{2}{|c|}{$\begin{array}{c}\text { Mean } \pm \text { standard deviation } \\
\text { (Range) }\end{array}$} & \multirow[t]{2}{*}{ CV } \\
\hline & & Al-Ahsa & Jubail & \\
\hline \multicolumn{2}{|c|}{ Body weight (mg) } & $\begin{array}{c}31.01 \pm 0.53 \\
(30.16-31.88)\end{array}$ & $\begin{array}{l}30.20 \pm 0.29^{\star \star} \\
(29.64-30.64)\end{array}$ & 1.73 \\
\hline \multicolumn{2}{|c|}{ Proboscis length (mm) } & $\begin{array}{r}3.22 \pm 0.06 \\
(3.10-3.30) \\
\end{array}$ & $\begin{array}{c}3.14 \pm 0.08^{\star \star} \\
(3.00-3.20)\end{array}$ & 2.70 \\
\hline \multicolumn{2}{|c|}{ Flagellum length (mm) } & $\begin{array}{c}1.73 \pm 0.03 \\
(1.67-1.75) \\
\end{array}$ & $\begin{array}{l}1.69 \pm 0.06^{\star \star} \\
(1.65-1.75)\end{array}$ & 2.34 \\
\hline \multicolumn{2}{|c|}{ Total antenna length (mm) } & $\begin{array}{l}2.75 \pm 0.05 \\
(2.71-2.82) \\
\end{array}$ & $\begin{array}{l}2.70 \pm 0.04^{\star \star} \\
(2.69-2.74)\end{array}$ & 1.62 \\
\hline \multirow{2}{*}{ Forewing } & Length (mm) & $\begin{array}{l}6.27 \pm 0.05 \\
(6.20-6.30)\end{array}$ & $\begin{array}{c}6.20 \pm 0.05^{\star \star} \\
(6.10-6.30)\end{array}$ & 1.09 \\
\hline & Width (mm) & $\begin{array}{l}2.36 \pm 0.04 \\
(2.30-2.40)\end{array}$ & $\begin{array}{c}2.24 \pm 0.07^{\star *} \\
(2.10-2.30)\end{array}$ & 2.32 \\
\hline \multirow{3}{*}{ Hindwing } & Length (mm) & $\begin{array}{r}4.40 \pm 0.08 \\
(4.30-4.50) \\
\end{array}$ & $\begin{array}{c}4.23 \pm 0.15^{\star \star} \\
(4.00-4.40) \\
\end{array}$ & 2.61 \\
\hline & Width (mm) & $\begin{array}{c}1.51 \pm 0.07 \\
(1.40-1.60) \\
\end{array}$ & $\begin{array}{c}1.47 \pm 0.07 \\
(1.40-1.60)\end{array}$ & 4.99 \\
\hline & No. hamuli & $\begin{array}{c}12.40 \pm 0.51 \\
(12.00-13.00)\end{array}$ & $\begin{array}{l}11.70 \pm 0.48^{\star \star} \\
(11.00-12.00)\end{array}$ & 6.06 \\
\hline \multicolumn{2}{|c|}{ Femur length (mm) } & $\begin{array}{c}1.73 \pm 0.04 \\
(1.65-1.75) \\
\end{array}$ & $\begin{array}{l}1.67 \pm 0.06^{\star} \\
(1.63-1.70)\end{array}$ & 3.03 \\
\hline \multicolumn{2}{|c|}{ Tibia length (mm) } & $\begin{array}{l}2.14 \pm 0.08 \\
(2.05-2.30) \\
\end{array}$ & $\begin{array}{c}2.07 \pm 0.35^{\star \star} \\
(1.95-2.10) \\
\end{array}$ & 10.70 \\
\hline \multicolumn{2}{|c|}{ Tibia width (mm) } & $\begin{array}{c}0.72 \pm 0.03 \\
(0.70-0.80) \\
\end{array}$ & $\begin{array}{c}0.69 \pm 0.03^{\star \star} \\
(0.67-0.70)\end{array}$ & 5.06 \\
\hline \multicolumn{2}{|c|}{ Metatarsus length (mm) } & $\begin{array}{c}1.39 \pm 0.02 \\
(1.35-1.43)\end{array}$ & $\begin{array}{l}1.36 \pm 0.04^{\star} \\
(1.33-1.40)\end{array}$ & 2.57 \\
\hline \multicolumn{2}{|c|}{$3^{\text {rd }}$ tergite length (mm) } & $\begin{array}{c}1.41 \pm 0.03 \\
(1.38-1.45)\end{array}$ & $\begin{array}{c}1.38 \pm 0.05 \\
(1.33-1.43)\end{array}$ & 2.52 \\
\hline \multicolumn{2}{|c|}{$3^{\text {rd }}$ sternite length (mm) } & $\begin{array}{r}1.70 \pm 0.06 \\
(1.65-1.75) \\
\end{array}$ & $\begin{array}{l}1.65 \pm 0.08^{\star} \\
(1.63-1.70) \\
\end{array}$ & 4.34 \\
\hline \multicolumn{2}{|c|}{$4^{\text {th }}$ tergite length (mm) } & $\begin{array}{r}1.35 \pm 0.06 \\
(1.30-1.45) \\
\end{array}$ & $\begin{array}{c}1.33 \pm 0.05 \\
(1.30-1.45) \\
\end{array}$ & 4.14 \\
\hline \multicolumn{2}{|c|}{$4^{\text {th }}$ sternite length (mm) } & $\begin{array}{c}1.54 \pm 0.05 \\
(1.50-1.56)\end{array}$ & $\begin{array}{c}1.52 \pm 0.02 \\
(1.50-1.55)\end{array}$ & 2.80 \\
\hline \multirow{2}{*}{$1^{\text {st }}$ Wax mirrc } & Length (mm) & $\begin{array}{c}0.82 \pm 0.02 \\
(0.79-0.85) \\
\end{array}$ & $\begin{array}{l}0.80 \pm 0.02^{\star} \\
(0.77-0.80) \\
\end{array}$ & 4.86 \\
\hline & Width (mm) & $\begin{array}{l}1.35 \pm 0.05 \\
(1.30-1.40\end{array}$ & $\begin{array}{l}1.26 \pm 0.05^{\star \star} \\
(1.20-1.30)\end{array}$ & 3.30 \\
\hline
\end{tabular}

${ }^{\star \star} p<0.01$ between provinces, ${ }^{\star} p<0.05$ between provinces. 


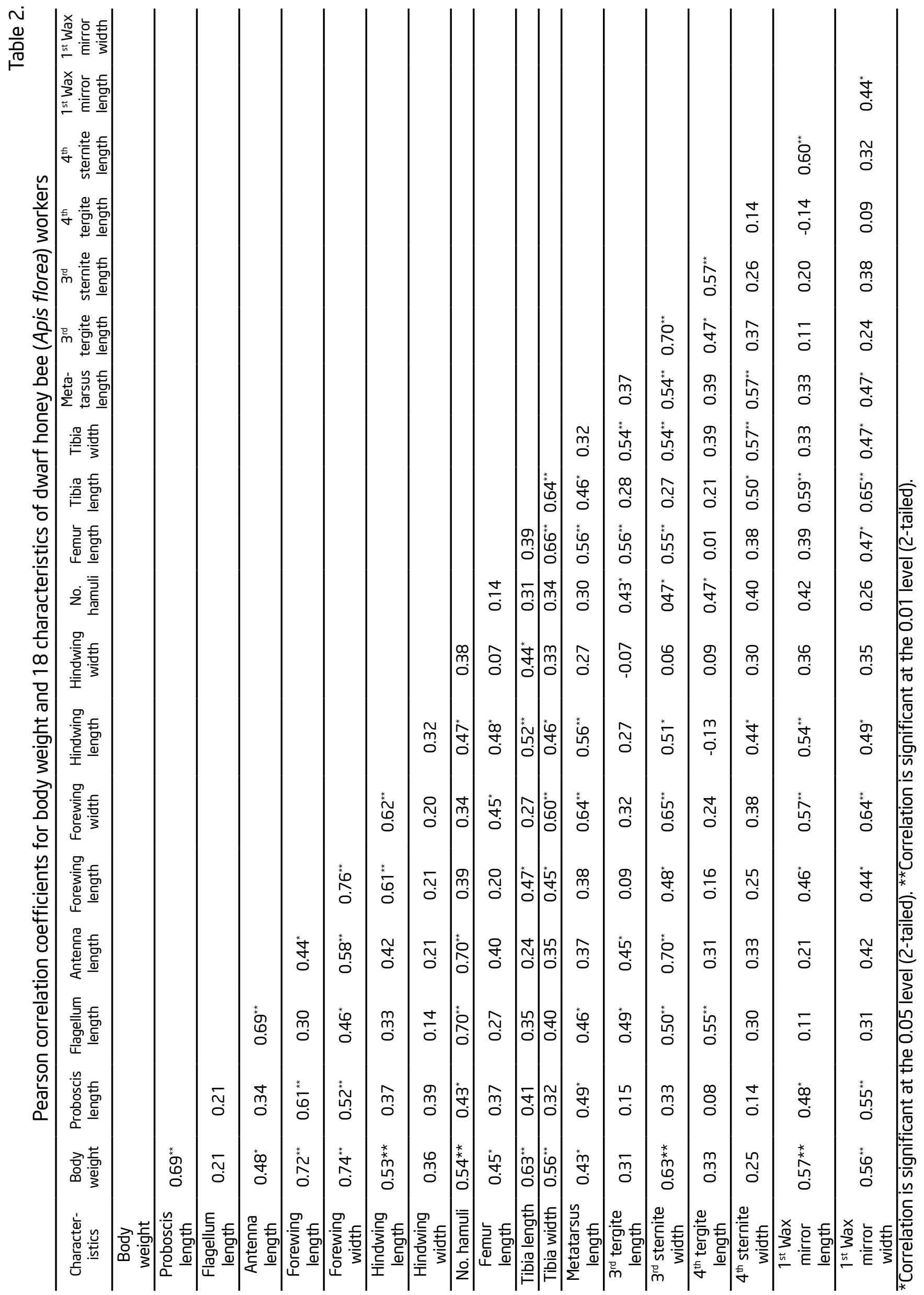


Table 3.

The mean values of meteorological factors

in the Al-Ahsa (A) and Jubail (J) provinces of Saudi Arabia from September to November of 2011

\begin{tabular}{ccccccccccc}
\hline Month & $\begin{array}{c}\text { Air temperature } \\
\left({ }^{\circ} \mathrm{C}\right)\end{array}$ & \multicolumn{2}{c}{$\begin{array}{c}\text { Relative humidity } \\
(\%)\end{array}$} & \multicolumn{2}{c}{$\begin{array}{c}\text { Wind velocity } \\
(\mathrm{m} / \mathrm{sec})\end{array}$} & Rainfall (mm) & \multicolumn{2}{c}{$\begin{array}{c}\text { Soil temperature } \\
\left({ }^{\circ} \mathrm{C}\right)\end{array}$} \\
\cline { 2 - 12 } & $\mathrm{A}$ & $\mathrm{J}$ & $\mathrm{A}$ & $\mathrm{J}$ & $\mathrm{A}$ & $\mathrm{J}$ & $\mathrm{A}$ & $\mathrm{J}$ & $\mathrm{A}$ & $\mathrm{J}$ \\
\hline Sep. & 33.39 & 32.90 & 27.42 & $46.20^{\star}$ & 2.17 & 2.35 & 0.00 & 0.00 & 35.27 & 34.63 \\
\hline Oct. & 27.81 & 28.05 & 37.48 & $51.19^{\star}$ & 2.06 & 2.81 & 0.00 & 0.00 & 32.39 & 32.40 \\
\hline Nov. & 20.13 & 20.75 & 48.67 & $57.04^{\star}$ & 2.66 & 3.30 & 0.03 & 0.06 & 27.56 & 28.65 \\
\hline *Significant difference between provinces at the 5\% level according to Duncan's Multiple Range Test.
\end{tabular}

\section{DISCUSSION}

The mean body weights of the $A$. florea workers were 30.20 and $31.01 \mathrm{mg}$ for the Jubail and Al-Ahsa provinces, respectively. This inter-locality difference was significant $(p<0.01)$, and could be related to environmental variations, especially relative humidity, which significantly differed between the two locations. Several groups have previously reported decreased daily activity of honey bees on days characterized by maximum relative humidity (Patil and Viraktamath, 2001; Kumar et al., 2002; Mordago et al., 2002). This activity decrease might affect food collection, and thus body size. Our results also confirmed the findings of Tahmasebi et al. (2002), who reported that more northern areas with higher altitudes and more precipitation have larger honeybees. In India, the weight of the $A$. florea worker ranges from 17.00 to $31.00 \mathrm{mg}$, with an average of $25.00 \mathrm{mg}$ (Kshirsagar et al., 1983). In northern Thailand, the average adult worker weighs $29.20 \mathrm{mg}$ in the winter and $31.20 \mathrm{mg}$ in the summer season (Burgett and Titayavan, 2004).

Among the measured head characteristics of the A. florea worker, the mean lengths of the proboscis, flagellum, and antenna were significantly affected $(p<0.01)$ by colony location. These differences could be correlated to body weight, as body weight was significantly positively correlated with proboscis length $(r=0.69 ; p<0.01)$ and antenna length $(r=0.48 ; p<0.05)$ (Tab. 2). The overall average proboscis, flagellum, and antenna lengths for A. florea workers from Saudi Arabia were 3.18, 1.71, and $2.73 \mathrm{~mm}$, respectively, which were lower than those measured from $A$. florea from Thailand: 3.33, 1.77 and $2.82 \mathrm{~mm}$, respectively (Chaiyawong et al., 2004) (Tab. 4).

Significant inter-locality variations were observed in the measured values for forewing length and width, hindwing length and width, and number of hamuli $(p<0.01)$. Inter-locality variations in wing character- istics have also been reported by Bhandari (1983), Sharma (1983), and Tahmasebi et al. (2002). The differences in measured wings characteristics could result from the significant $(p<0.01)$ variation in body size. Body weight was found to significantly $(p<0.01)$ positively correlate with forewing length $(r=0.72)$ and width ( $r=0.74)$, hindwing length ( $r=0.53)$, and number of hamuli $(r=0.54)$. The mean values were $6.24 \mathrm{~mm}$ for forewing length, $2.30 \mathrm{~mm}$ for forewing width, $4.32 \mathrm{~mm}$ for hindwing length, $1.49 \mathrm{~mm}$ for hindwing width, and 12.05 hamuli, which were each higher than the values reported for workers from Thailand-except for forewing length, which was lower (Rinderer et al., 1995). Chaiyawong et al. (2004) reported the same trend for forewing length and hamuli number. Forewing length in the present study $(6.24 \mathrm{~mm})$ was lower than those reported from Cambodia $(6.58 \mathrm{~mm})$, Sri-Lanka $(6.85 \mathrm{~mm})$, Myanmar (6.44 mm), Nepal (6.33 mm), Oman $(6.52 \mathrm{~mm})$ and Pakistan $(6.61 \mathrm{~mm})$, while it was higher than those reported from India $(6.13 \mathrm{~mm})$, Iran $(6.14 \mathrm{~mm})$, Thailand $(6.17 \mathrm{~mm})$, and Vietnam (6.23 mm) (Hepburn et al., 2005).

We also observed significantly $(p<0.05)$ different measured leg characteristics between workers from the two locations in Saudi Arabia. Body weight was found to be significantly positively correlated with femur length ( $r=0.45 ; p<0.05)$, tibia length ( $r=0.63$; $p<0.01)$, and tibia width ( $r=0.56$; $p<0.01)$ (Tab. 2). The overall average values for the whole population were $1.70 \mathrm{~mm}$ for femur length, $2.11 \mathrm{~mm}$ for tibia length, $0.71 \mathrm{~mm}$ for tibia width, and $1.38 \mathrm{~mm}$ for metatarsus length, which were higher than the values obtained from south India (femur length, $1.67 \mathrm{~mm}$; tibia length, 2.09; and metatarsus length, 1.29), but lower than those from Iran (femur length, $1.83 \mathrm{~mm}$; tibia length, 2.30; and metatarsus length, $1.41 \mathrm{~mm}$ ) (Tab. 4). In Thailand, the same trend was observed for femur and tibia lengths, while the opposite trend was observed for metatarsus length (Rinderer et al., 1995; Chaiyawong et al., 2004). 
$\frac{\sqrt{2}}{\stackrel{9}{\circ}}$

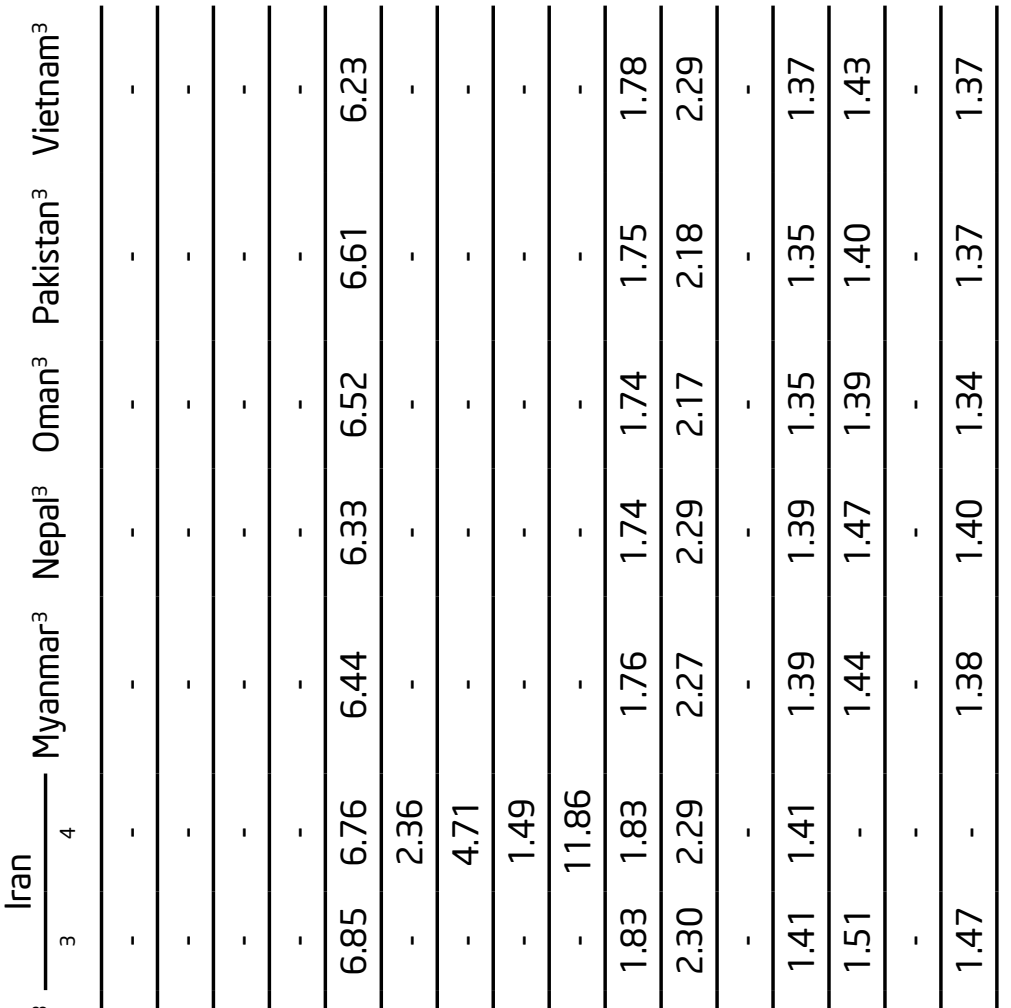

드

$\stackrel{0}{0}=0$

늘

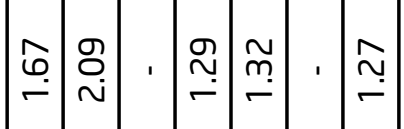

هั

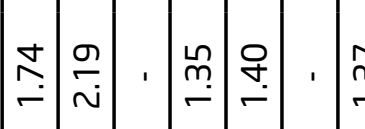

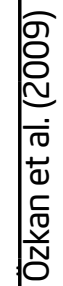

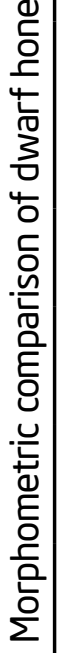

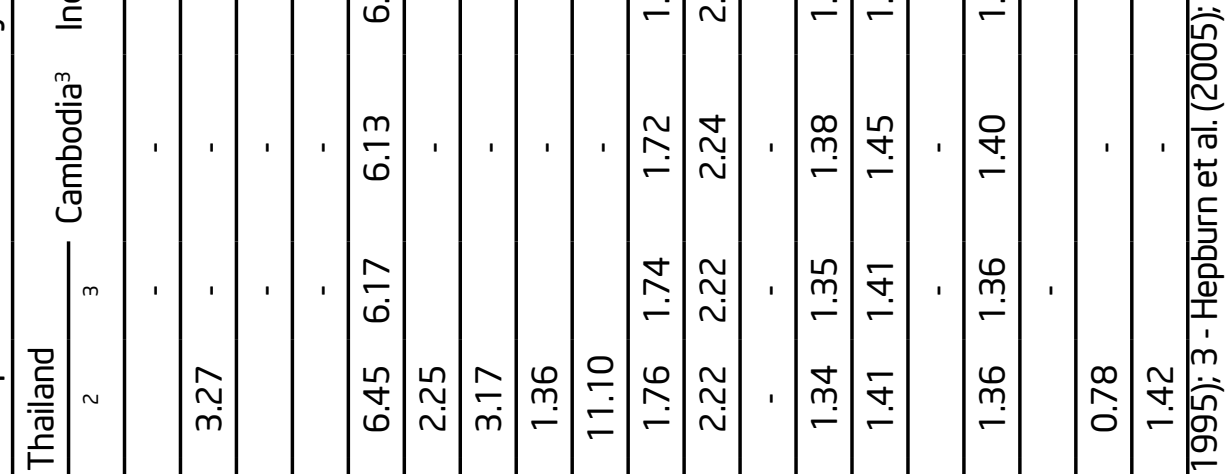

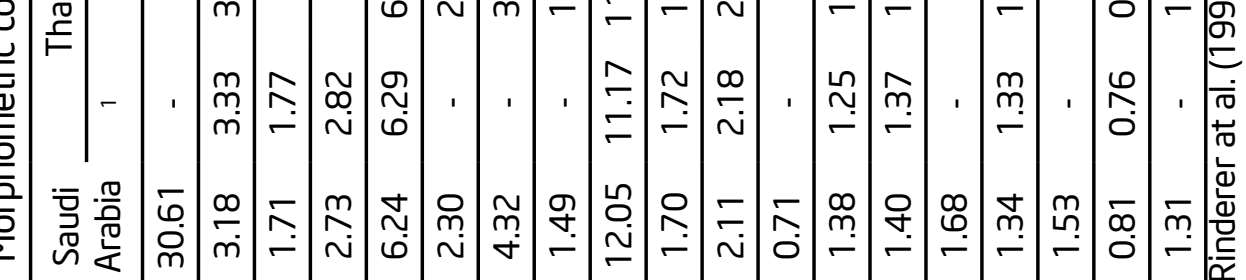

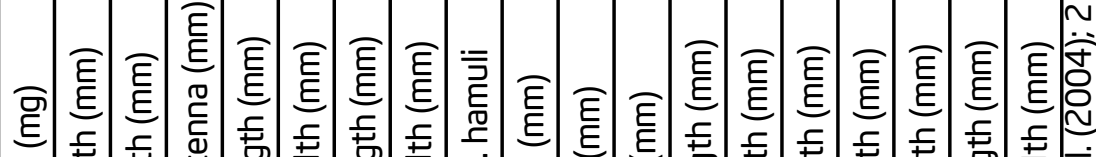

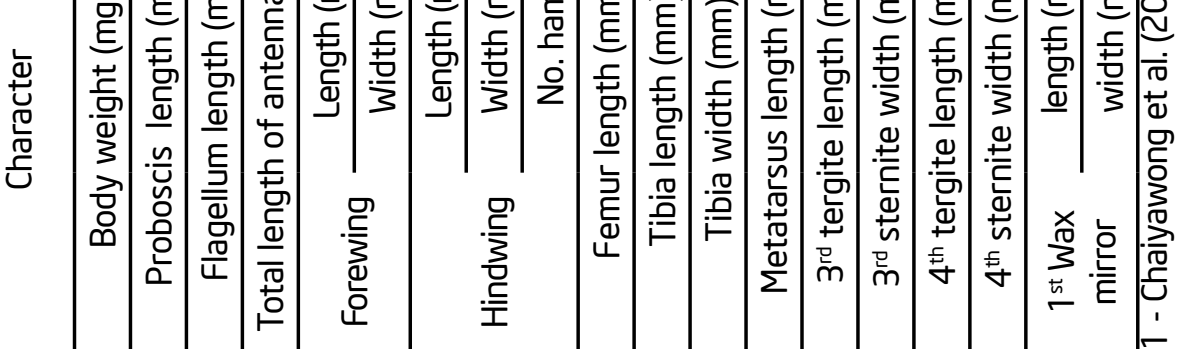




\section{J. APIC. SCL. VOL. 58 NOV. 12014}

The mean values for length and width of the $3^{\text {rd }}$ sternite and $1^{\text {st }}$ wax mirror significantly differed between workers from Al-Ahsa and Jubail. These differences were related to variations in worker body size. Body weight was significantly $(p<0.01)$ positively correlated with $3^{\text {rd }}$ sternite length $(r=0.63)$ and $1^{\text {st }}$ wax mirror length ( $r=0.57)$ and width $(r=0.56)$. The mean lengths of the $3^{\text {rd }}$ and $4^{\text {th }}$ tergite were 1.40 and 1.34 $\mathrm{mm}$, respectively. The same values were recorded for $3^{\text {rd }}$ tergite in India and Pakistan, and $4^{\text {th }}$ tergite in Oman (Hepburn et al., 2005). The present values were higher than those reported from Thailand (Chaiyawong et al., 2004) and Sri-Lanka (Hepburn et al., 2005), but lower than those reported from other studies in Thailand (Rinderer et al., 1995; Hepburn et al., 2005), as well as from Cambodia, Iran, Myanmar, Nepal, and Vietnam (Hepburn et al., 2005). Regarding the $1^{\text {st }}$ wax mirror for bees from Saudi Arabia in the present study, the mean length was longer than those from Thailand (Rinderer et al., 1995; Chaiyawong et al., 2004), while the mean width was shorter than those from Thailand (Rinderer et al., 1995).

\section{CONCLUSION}

It can be concluded that body size and most morphometric characteristics of dwarf honey bee ( $A$. florea) workers significantly varied according to geographical origin. Additionally, most measured values of characteristics of dwarf bees in Saudi Arabia were lower than those previously reported from Pakistan, Nepal, Myanmar, Thailand, India, and Iran, while they were higher than those reported from Sri Lanka.

\section{REFERENCES}

Bhandari V. C. (1983) Biometrical studies on Apis florea F. and Apis dorsata F. of north-western India. Thesis. Himachal Pradesh University Simla. India. 92 pp.

Burgett D. M., Titayavan M. (2004) Apis florea F. - colony biometrics in Northern Thailand. In: Proceeding of the $8^{\text {th }}$ IBRA International Conference of Tropical Bees and VI Encontrosobre Abelha S. Ribeirao Preto - Brasil. 6-10 September 2004: 46-54.

Chaiyawong T. (2001) Morphometric study of Apis florea in Thailand. M.Sc. Thesis. Chulalongkorn Univ. Bangkok. Thailand. 108 pp.

Chaiyawong $T$., Deowanish S., Wongsiri S., Slyvester $H$. (2004) Multivariate morphometric study of Apis florea in Thailand. Journal of Apicultural Research 43(3): 123-127.
El-Shafie H. F., Mogga J. B., Basedow T. H. (2002) Studies on the possible competition for pollen between the honey bee, Apis mellifera sudanensis, and the imported dwarf honey bee Apis florea (Hym., Apidae) in North-Khartoum (Sudan). Journal of Applied Entomology 126: 557-562.

Free J. (1981) Biology and behavior of the honey bee Apis florea, and possibilities for beekeeping. Bee World 62 (2): 46-59.

Haddad N., de Miranda J. R., Bataena A. (2008) Discovery of Apis florea in Aqaba, Jordan. Journal of Apicultural Research 47: 173-174.

Haddad N., Fuchs S., Hepburn H. R., Radloff S. E. (2009) Apis florea in Jordan: source of the founder population. Apidologie 40: 508-512.

Hepburn H. R., Radloff S. E., Otis G. W., Fuchs S., Verma K., Tan L. R., Chaiyawong T., Tahmasebi G., Wongsiri S. (2005) Apis florea: morphometrics, classification and biogeography. Apidologie 36: 359-376.

Kshirsagar K. K., Muvel K. S., Mittal M. C., Phadke R. P. (1983) Some observations on the behavior of Apis florea F. In: Proceeding of $2^{\text {nd }}$ International Conference of Apiculture in Tropical Climates. New-Delhi. 29 February - 4 March 1983: 356-366.

Kumar M., Singh R., Chand H. (2002) Foraging activity of Apis cerana indica and Apis mellifera visiting sunflower (Helianthus annuus L.). Shashpa 9 (1): 31-34.

Mogga G. B., Ruttner F. (1988) Apis florea in Africa; source of the founder population. Bee World 69: 100-103.

Mordago L. N., Carvalho C. F., Souza B., Santana M. P. (2002) Fauna of bees (Hymenoptera: Apoidea) on sunflower flowers, Helianthus annuus L, in Lavras-MG, Brazil. Ciencia e Agrotecnologia 26 (6): $1167-1177$.

Özkan A., Gharleko M., Özden B., Kandemir I. (2009) Multivariate morphometric study on Apis florea distributed in Iran. Turkish Journal of Zoology 33: 93-102.

Patil B. S., Viraktamath S. (2001) Foraging behavior of two species of honey bee on sesame. Karnataka Journal of Agricultural Science 14 (3): 796-798.

Rinderer T. E., Oldroyd B. P., Wongsiri S., Sylvester H. A., de Guzman L. I., Stelzer J. A., Riggio R. M. (1 995) A morphological comparison of the dwarf honey bees of southeastern Thailand and Palawan, Philippines. Apidologie 26: 387-394. 


\section{_ HL-KAHTHNI AND THHH__ Morphometrics of dwarf honey bee}

Ruttner F. (1988) Biogeography and taxonomy of honeybees. Springer-Verlang. Berlin. 284 pp.

SAS Institute (2003) SAS/STAT User's Guide release 9.1. SAS Institute Inc, Cary, NC 27513.

Sharma P. C. (1983) Morphometric studies on Apis florea F. and Apis dorsata F. of Himachal Pradesh and Punjab. Thesis. Himachal Pradesh University. India. 83 pp.

Tahmasebi G., Ebadi R., Tajabadi N., Akhoundi M., Faraji S. (2002) The effects of geographical and climatic conditions on the morphological variation and separation of Iranian small honeybee (Apis florea F.) populations. Journal of Science and Technology of Agriculture and Natural Resources. Water and Soil Science 6(2): 169-176.
Wongsiri S., Chanchao C., Deowanish S., Aemprapa S. Chaiyawong T., Petersen S., Leepitakrat S. (2000) Honey bee diversity and beekeeping in Thailand. Bee World 81 (1): 20 -

29.

Wongsiri S., Lekprayoon C., Thapa R., Thirakupt K., Rinderer T. E., Sylvester H. A., Oldroyd B. P., Booncham U. (1996) Comparative biology of Apis andreniformis and Apis florea in Thailand. Bee World 77: 23-35. 